\title{
Role of oleanolic acid in relieving psoriasis and its underlying mechanism of action
}

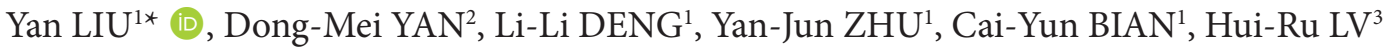

\begin{abstract}
The present study aimed to determine whether oleanolic acid (Ole) could be used to treat psoriasis and its related underlying mechanism of action via in vitro analysis. HaCaT cells were stimulated with IL-22 to established an in vitro psoriasis cell model. MTT, flow cytometry and TUNEL assays, respectively. Transmission electron microscopy was used to observe the cell ultrastructure. LC3B protein expression levels were analyzed using immunofluorescence, other protein expression levels were determined using western blotting. Cell viability was significantly increased, while the apoptotic rate was significantly decreased in the model group $(\mathrm{P}<0.001)$. In addition, Notch1, Hes1, beclin 1 and LC3B protein expression levels were significantly downregulated, while P62 protein expression levels were significantly upregulated in the model group compared with the control group $(\mathrm{P}<0.001)$. Supplementation of Ole, the increased levels of proliferation were significantly suppressed, while cell apoptosis was significantly increased $(\mathrm{P}<0.05)$ in a dose-dependent manner, which was discovered to occur via Notch1 upregulation. Notably, the transfection with small interfering RNA-Notch1 significantly reversed the effect of Ole treatment $(\mathrm{P}<0.001)$ and the levels of autophagy were also decreased. In conclusion, the findings of the current study suggested that Ole may relieve psoriasis via upregulating Notch1, which subsequently regulates cell autophagy.
\end{abstract}

Keywords: oleanolic acid; psoriasis; notch 1 receptor; HaCaT cells; autophagy.

Practical Application: oleanolic acid could relieving psoriasis.

\section{Introduction}

Psoriasis is a common and recurring chronic inflammatory skin condition, and its prevalence among adults ranges from 0.91 to $8.5 \%$ in different Please clarify, are you referring to different countries and ethnic (Griffiths et al. 2017). However, the exact pathogenesis of psoriasis remains unclear. At present, studies have confirmed that the onset of psoriasis is closely associated with autoimmunity and inflammation, and the excessive proliferation of keratinocytes and parakeratosis are key factors underlying its pathogenesis (Perera et al. 2012). Autophagy is a process of self-phagocytosis in cells that occurs when cells are under stress conditions, such as those of nutrient deprivation or infection (Jo, et al. 2012). It was previously reported that oleanolic acid (Ole), which is an extensively used plant-derived triterpenoid, exerted effective antioxidant effects in cell model (Guo et al. 2020). In an in vitro antioxidant activity evaluation model, Ole was discovered to clear free radicals and inhibit reactive oxygen species (ROS) generation through chemical reactions, or by inhibiting lipid peroxidation or stimulating the cellular antioxidant defense mechanisms (Wang et al. 2020). In addition, Ole has been demonstrated to possess hepatoprotective, antiinflammatory, anticancer and other pharmacological properties (Zolnourian et al. 2019, Zhang et al. 2019a). Moreover, Ole was discovered to exert therapeutic benefits in liver cancer (Zhou et al. 2020), diabetes-induced cell injury (Chen et al. 2019) and bladder cancer (Song et al. 2017) via regulation of autophagy. Kim et al.
(Varshney and Saini, 2018) found autophagy was correlation with psoriasis. However, to the best of our knowledge, the effects of Ole in psoriasis remain unknown.

Previous studies have reported that the levels of autophagy in psoriasis skin lesions were lower compared with those in the normal skin in vitro study (Haruna, et al. 2008); blocking autophagy could significantly increase the secretion of inflammatory factors in human epidermal cells (Lee et al. 2011); and increasing the levels of autophagy in psoriasis skin lesions, mainly via regulation of hes family bHLH transcription factor 1 (Hes1), beclin 1, LC3B and P62 protein expression (Zhang et al. 2019b), may represent a potential therapeutic strategy for psoriasis. However, the effects of Ole on the autophagy of human keratinocytes remain unclear. Therefore, the present study aimed to investigate the effect of Ole on the autophagy of $\mathrm{HaCaT}$ cells and to determine the related underlying mechanism of action.

\section{Materials and methods}

Reagents and antibodies. Ole (cat. no. O5504; mass fraction, $\geq 97 \%$ ), DMSO (cat. no. V900090) and MTT reagent (cat. no. V900888) were purchased from Sigma-Aldrich (Merck KGaA); the HaCaT cell line was purchased from the American Type Culture Collection; EDTA-free pancreatin, DMEM and FBS were purchased from Gibco (Thermo Fisher Scientific, Inc.); the rabbit anti-LC3B 
monoclonal antibody was obtained from Abcam, cat.ab239416, UK; the rabbit anti-P62 monoclonal antibody was purchased from Abcam, cat.ab91526, UK; the HRP-conjugated goat anti-rabbit secondary antibody was acquired from Santa Cruz Biotechnology, Inc.; the anti-Notch1 (cat. no. ab52301), antibeclin 1 (cat. no. ab217179), anti-Hes1 (cat. no. ab119776) and anti-GAPDH (cat. no. ab8245) antibodies were obtained from Abcam; and the TUNEL Apoptosis Staining kit was purchased from Beyotime Institute of Biotechnology (cat.no. C1090).

Cell culture. HaCaT cells (which were authenticated via STR profiling) were cultured in DMEM (Gibco, Grand Island, NY, USA) supplemented with $10 \%$ FBS (Thermo Fish, Waltham, MA, USA), and maintained in an incubator with $5 \% \mathrm{CO}_{2}$ at $37^{\circ} \mathrm{C}$. Cells in the logarithmic growth phase were collected and used in subsequent experiments.

Establishment of the psoriasis cell model. A psoriasis cell model was established as previously described (Wu et al. 2020). Briefly, upon the confluence reaching 60-70\%, HaCaT cells were cultured in serum-free DMEM for $12 \mathrm{~h}$, then stimulated with $100 \mathrm{ng} / \mathrm{mL}$ IL-22 for $12 \mathrm{~h}$ to simulate the proliferation of the cells.

Preparation of Ole. Ole was dissolved in DMSO and stored in the dark at a concentration of $10.0 \mathrm{~mol} / \mathrm{L}$ at $-20^{\circ} \mathrm{C}$; the final concentration of DMSO was $\leq 0.1 \%$. Ole was diluted in DMEM to working concentrations of $25.0,50.0,100.0$ or $200.0 \mu \mathrm{mol} / \mathrm{L}$.

Group treatment. NC: the $\mathrm{HaCaT}$ cells were cultured by DMEM with 10\% FBS; Model: the HaCaT cell were treated as psoriasis cell model; Ole-Low: HaCaT cell which were treated as psoriasis cell model were treated by $25.0 \mu \mathrm{mol} / \mathrm{L}$ Ole; OleMiddle: $\mathrm{HaCaT}$ cell which were treated as psoriasis cell model were treated by $50.0 \mu \mathrm{mol} / \mathrm{L}$ Ole; Ole-High: $\mathrm{HaCaT}$ cell which were treated as psoriasis cell model were treated by $100.0 \mu \mathrm{mol} / \mathrm{L}$ Ole; Model+si-NC: $\mathrm{HaCaT}$ cell which were treated as psoriasis cell model were transfected with si-NC (negative control); Ole: $\mathrm{HaCaT}$ cell which were treated as psoriasis cell model were treated by $100.0 \mu \mathrm{mol} / \mathrm{L}$ Ole; Ole+si-Notch1: $\mathrm{HaCaT}$ cell which were transfected with si-Notch 1 and treated as psoriasis cell model were treated by $100.0 \mu \mathrm{mol} / \mathrm{L}$ Ole

Cell transfection. Cells in the logarithmic growth phase were seeded into a 6 -well microplate at a density of $2 \times 10^{5}$ cells/ well. Upon reaching $60 \%$ confluence, cell transfection was performed in accordance with the manufacturer's instructions. Small interfering RNA (si)-negative control (NC) (sense, 5'-UUCUCCGAACGUGUCACGUTT-3' and antisense, 5'ACGUGACACGUUCGGAGAATT-3') and si-notch 1 receptor (Notch1; sense, 5'- UGGACAAGAUCGAUGGCUATT-3' and antisense, 5'- UAGCCAUCGAUCUUGUCCATT-3') were designed and synthesized by Nanjing KeyGen Biotech Co., Ltd (KG-D-19060715). Following transfection, the cells were further incubated in an incubator containing $5 \% \mathrm{CO}_{2}$ at $37^{\circ} \mathrm{C}$ ready for use in subsequent experiments. The cell transfection efficiencies were shown in Supplementary Figure 1.

MTT assay. Cells in all groups were treated by difference methods for 48 then $20 \mu \mathrm{L}$ MTT was added to each well for further incubation for $4 \mathrm{~h}$. Following incubation, the medium was discarded and $100 \mu \mathrm{L}$ DMSO was added to each well. After the mixture had been centrifuged as $8,000 \mathrm{xg}$ at $4^{\circ} \mathrm{C}$ for $10 \mathrm{~min}$, the absorbance of each well was measured at a wavelength of $570 \mathrm{~nm}$ using an ELISA microplate reader. The assay was repeated three times to calculate the proliferative rate of the cells.

Flow cytometric analysis of apoptosis. Cells in all groups were treated by difference methods for 48 , then digested with EDTA-free pancreatin. The cells were washed with pre-cooled PBS buffer solution twice and centrifuged at 1,000 $\mathrm{xg}$ for $5 \mathrm{~min}$ to collect $1 \times 10^{5}$ cells. Subsequently, $5 \mu \mathrm{L}$ Annexin V-FITC and PI were added to the cells and mixed, following which the cells were incubated in the dark at room temperature for 5-10 min. Apoptotic cells were analyzed within $1 \mathrm{~h}$ using a flow cytometer at an excitation wavelength of $488 \mathrm{~nm}$ and an emission wavelength of $530 \mathrm{~nm}$. The early apoptotic cells in the lower right quadrant and the late apoptotic cells in the upper right quadrant were counted as apoptotic cells. The apoptotic rate was calculated as the number of apoptotic cells/total number of cells. The analysis was repeated three times.

TUNEL assay. Cells in all groups were treated accordingly for $48 \mathrm{~h}$, then washed with PBS three times. The TUNEL assay was performed using a TUNEL Apoptosis staining kit, according to the manufacturer's protocol. After staining, the cells were sealed with anti-fluorescence quenching sealing solution containing DAPI and visualized using a fluorescence microscope in three highly magnified (x200) randomly selected fields of view, with each field containing $\leq 100$ cells. The apoptotic rate of $\mathrm{HaCaT}$ cells was calculated using the following equation: Apoptotic rate $(\%)=$ FITC-positive cells $/ 100 \times 100 \%$. The average apoptotic rate was obtained from three fields. The assay was repeated in triplicate.

Transmission electron microscopy (TEM). Autophagosome detection was performed using TEM. Briefly, cells in each group were treated accordingly for $48 \mathrm{~h}$ and then washed with PBS thrice. Cells were subsequently collected and centrifuged at $1,200 \mathrm{x} g$ for $5 \mathrm{~min}$. The supernatant was discarded and cells were fixed with $4 \%$ glutaraldehyde overnight. Following incubation, the cells were rinsed, dehydrated and embedded, then cut into ultra-thin slices, which were observed under a transmission electron microscope and photographed.

Western blotting. Cells in each group were treated accordingly for $48 \mathrm{~h}$ and then washed with PBS thrice. Total protein was extracted from the cells using RIPA lysis buffer supplemented with a protease inhibitor. The cells were centrifuged at high speed to extract the supernatant and total protein was quantified using a BCA protein assay kit (cat. no. ab102536; Abcam). Loading buffer was subsequently mixed with the protein, and boiled, following which $50 \mu \mathrm{g}$ protein/lane was separated via SDS-PAGE. The separated proteins were transferred to PVDF membranes and blocked with 3\% BSA at room temperature for $2 \mathrm{~h}$. The membranes were then incubated with the following primary antibodies overnight at $4{ }^{\circ} \mathrm{C}$ : Anti-Notch1 (1:500), anti-Hes1 (1:500), anti-beclin 1 (1:500), anti-P62 (1:500) and anti-GAPDH (1:500). Following the primary antibody incubation, the membranes were incubated with an HRP-conjugated antirabbit secondary antibody (1:2,000; cat. no. ab6728, Abcam) for $2 \mathrm{~h}$. Protein bands were visualized using chemiluminescence. The experiment was repeated three times to obtain the average protein expression. 
Detection of the autophagy marker protein, LC3B, using immunofluorescence. Cells in each group were treated accordingly for $48 \mathrm{~h}$, washed with PBS thrice, then fixed with $4 \%$ formaldehyde at room temperature for $10 \mathrm{~min}$. Subsequently, the cells were washed with PBS twice and incubated with $0.5 \%$ Triton X-100 at room temperature for $5 \mathrm{~min}$. The cells were subsequently washed with PBS twice and incubated with 5\% BSA at room temperature for $1 \mathrm{~h}$. Then, the cells were incubated with an anti-LC3B antibody (1:200) for $1 \mathrm{~h}$ at room temperature; the primary antibody was replaced with PBS for the control group. Following the primary antibody incubation, the cells were washed with PBS twice and incubated with the corresponding fluorescent-conjugated secondary antibody (1:2,000; cat. no. ab6728, Abcam). The cells were washed with PBS, counterstained with DAPI, and further washed with PBS before being sliced and sealed with glycerinum. Stained cells were observed using a fluorescence microscope in five randomly selected fields of view (magnification, x200) to count the number of autophagosome-positive cells and calculate the percentage of positive cells. Cells with more than three high-density green fluorescent spots in the perinuclear and extranuclear regions were regarded as autophagosome-positive cells. The experiment was repeated three times to calculate the average value.

Statistical analysis. Statistical analysis was performed using SPSS 22.0 software (IBM Corp.) and data are presented as the mean \pm SD. Statistical differences between groups were determined using one-way ANOVA followed by Tukey post hoc test. $\mathrm{P}<0.05$ was considered to indicate a statistically significant difference.

\section{Results}

Effects of different concentrations of Ole on the viability of the HaCaT cell psoriasis model. Compared with the $0 \mu \mathrm{mol} / \mathrm{L}$ group, the proliferative rate of $\mathrm{HaCaT}$ cells in the $200.0 \mu \mathrm{mol} / \mathrm{L}$ group was significantly inhibited with apoptosis rate significantly up-regulating $(\mathrm{P}<0.001$; Figure $1 \mathrm{~A}, \mathrm{C})$, while no significant differences were observed among the 25.0, 50.0 and 100.0 $\mu \mathrm{mol} / \mathrm{L}$ groups in cell viability and apoptosis rate (all $\mathrm{P}>0.05$; Figure $1 \mathrm{~A})$. Thus, it could be inferred that, in a normal environment, Ole at concentrations of 25.0, 50.0 and $100.0 \mu \mathrm{mol} / \mathrm{L}$, was nontoxic to HaCaT cells. A psoriasis cell model was subsequently established by stimulating HaCaT cells with $100 \mathrm{ng} / \mathrm{mL}$ IL22 for $12 \mathrm{~h}$. Compared with the control group, the proliferative rate was significantly increased in the model group $(\mathrm{P}<0.001$; Figure 1B). After Ole intervention, compared with the model group, the proliferative rates in the Ole groups were significantly inhibited (all $\mathrm{P}<0.05$; Figure $1 \mathrm{~B}$ ), and significant differences were identified in the proliferative rates among the different Ole groups (all $\mathrm{P}<0.05$; Figure 1B). 25.0, 50.0 and $100.0 \mu \mathrm{mol} / \mathrm{L}$ Ole was safe to $\mathrm{HaCaT}$ cell in normal treatment; in HaCaT cell psoriasis model, 25.0, 50.0 and $100.0 \mu \mathrm{mol} / \mathrm{L}$ Ole had effects to depress HaCaT hyperproliferation.

Ole promoted cell apoptosis in HaCaT cell psoriasis model. The results from the flow cytometry and TUNEL staining assays revealed that, compared with the control group, the apoptotic rate was significantly decreased in the model group (all $\mathrm{P}<0.001$; Figure $2 \mathrm{~A}$ and $\mathrm{B}$ ). Following Ole intervention, compared with the model group, the apoptotic rate was significantly increased in all Ole groups (all $\mathrm{P}<0.05$; Figure $2 \mathrm{~A}$ and $\mathrm{B}$ ). Moreover, significant differences were observed in the apoptotic rates among the different Ole groups (all $\mathrm{P}<0.05$; Figure $2 \mathrm{~A}$ and $\mathrm{B}$ ). In $\mathrm{HaCaT}$ cell psoriasis model, 25.0, 50.0 and $100.0 \mu \mathrm{mol} / \mathrm{L} \mathrm{Ole}$ had effects to promote $\mathrm{HaCaT}$ cell apoptosis; and $100.0 \mu \mathrm{mol} / \mathrm{L}$ Ole had best effects.

Ole promoted the autophagy of $\mathrm{HaCaT}$ cell psoriasis model . The formation of autophagosomes was visualized using TEM. Autophagosomes with a bilayer membrane and containing numerous organelles and folded proteins were observed in the control group, while no autophagosomes were observed in the model group. After Ole intervention, the number of autophagosomes in all the Ole groups was increased (Figure 3). In $\mathrm{HaCaT}$ cell psoriasis model, 25.0, 50.0 and 100.0 $\mu \mathrm{mol} / \mathrm{L} \mathrm{Ole}$ had effects to increase autophagosome number; and $100.0 \mu \mathrm{mol} / \mathrm{L}$ Ole had best effects.

Ole regulated the expression levels of Notch1, Hes 1, Beclin 1 and P62 proteins in HaCaT cell psoriasis model The results of the western blotting experiment revealed that, compared with the control group, the protein expression levels of Notch1, Hes1 and beclin 1 were significantly downregulated in the model group, while the protein expression levels of P62 were significantly upregulated (all $\mathrm{P}<0.001$; Figure 4). After Ole intervention, compared with the model group, the protein expression levels of Notch1, Hes 1 and beclin 1 were significantly upregulated in all Ole groups, while the protein expression levels of P62 were significantly downregulated (all $\mathrm{P}<0.001$; Figure 4). Furthermore, there were significant differences observed in the expression levels of these proteins among the Ole groups (all $\mathrm{P}<0.05$; Figure 4). 25.0, 50.0 and $100.0 \mu \mathrm{mol} / \mathrm{L}$ Ole improved psoriasis cell model might be correlation with Notch1, Hes1, Beclin1 and P62 proteins changing; and $100.0 \mu \mathrm{mol} / \mathrm{L}$ Ole had best effects.

Ole increased the protein expression levels of $L C 3 B$ in $\mathrm{HaCaT}$ cell psoriasis model. The results of the cell immunofluorescence analysis showed that, compared with the control group, the protein expression levels of LC3B were significantly decreased in the model group $(\mathrm{P}<0.001$; Figure 5$)$. Compared with the model group, the protein expression levels of LC3B were significantly upregulated in all Ole groups (all $\mathrm{P}<0.05$; Figure 5 ). Furthermore, the differences in the expression levels of LC3B protein among the Ole groups were statistically significant (all $\mathrm{P}<0.05$; Figure 5). 25.0, 50.0 and $100.0 \mu \mathrm{mol} / \mathrm{L}$ Ole improved psoriasis cell model might be correlation with autophagy; and $100.0 \mu \mathrm{mol} / \mathrm{L}$ Ole had best effects.

Notch1 knockdown improved the Ole-induced inhibition of $\mathrm{HaCaT}$ cell viability. No significant difference in the proliferative rate was identified between the model and model + si-NC groups ( $\mathrm{P}>0.05$; Figure 6 ), while the proliferative rate in the Ole groups was significantly decreased (all $\mathrm{P}<0.001$; Figure 6). Following the transfection of si-Notch1 into cells, the proliferative rate in the Ole + si-Notch 1 group was significantly increased compared with that in the Ole groups (all $\mathrm{P}<0.001$; Figure 6). With Notch1 knockdown, Ole's treatment effects was disappear in $\mathrm{HaCaT}$ cell psoriasis model.

Notch1 knockdown depressed the Ole-induced increased in the apoptosis of HaCaT cell psoriasis model. The results of the flow cytometry and TUNEL staining assays revealed that, compared 
A

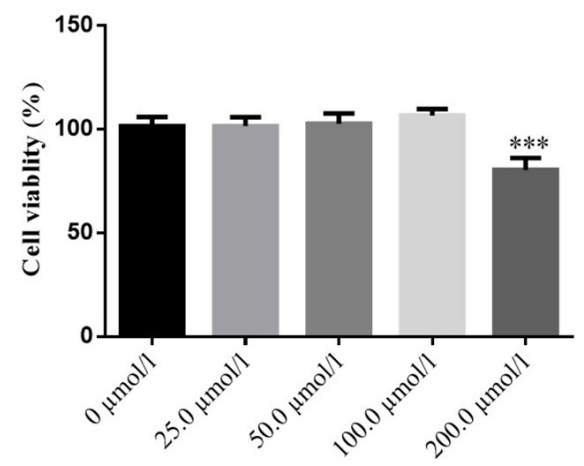

$\mathrm{B}$

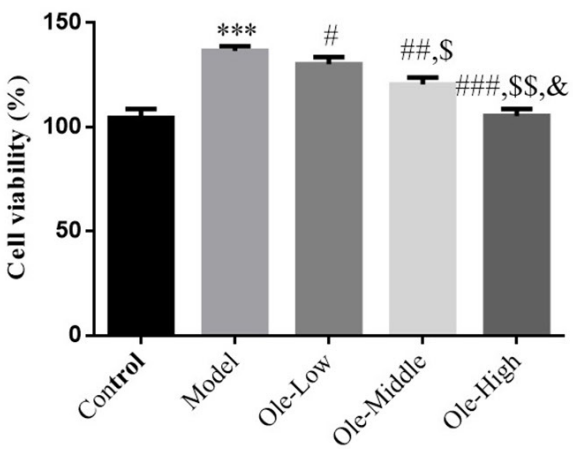

$\mathrm{C}$
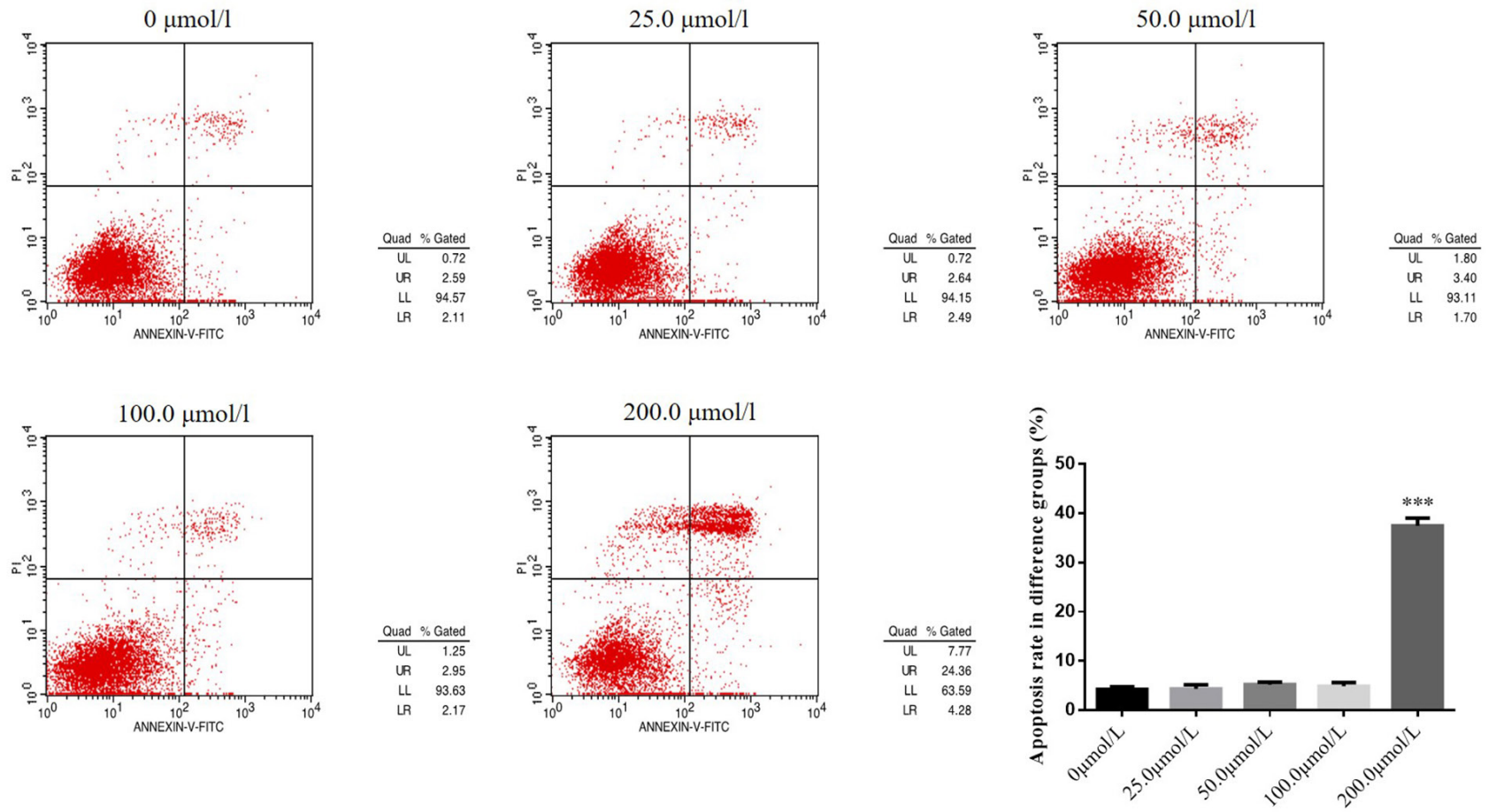

Figure 1. Effects of different concentrations of Ole on the proliferative rate of a HaCaT cell psoriasis model. (A) Cell viability following treatment with difference concentrations of Ole was determined using an MTT assay. ${ }^{* *} \mathrm{P}<0.001 \mathrm{vs} .0 \mu \mathrm{mol} / \mathrm{L}$. (B)Cell viability in difference groups was determined using an MTT assay. Control, HaCaT cells were treated with normal medium; model, HaCaT cells were stimulated with IL-22; Olelow, model group cells were subsequently treated with low-dose $(25.0 \mu \mathrm{mol} / \mathrm{L})$ Ole; Ole-middle, model group cells were subsequently treated with middle-dose $(50.0 \mu \mathrm{mol} / \mathrm{L})$ Ole; Ole-high, model group cells were subsequently treated with high-dose $(100.0 \mu \mathrm{mol} / \mathrm{L}) \mathrm{Ole}{ }^{* * *} \mathrm{P}<0.001$ vs. control; ${ }^{\#} \mathrm{P}<0.05,{ }^{\# \#} \mathrm{P}<0.01,{ }^{\# \# \#} \mathrm{P}<0.001$ vs. model; ${ }^{\$} \mathrm{P}<0.05,{ }^{\$ \$} \mathrm{P}<0.01$ vs. Ole-low; ${ }^{\circledR} \mathrm{P}<0.05$ vs. Ole-middle. Ole, oleanolic acid. (C) Cell apoptosis rate of difference groups was determined using flow cytometry. ${ }^{* * *} \mathrm{P}<0.001 \mathrm{vs.} 0 \mu \mathrm{mol} / \mathrm{L}$.

with the model group, the apoptotic rate in the model + si-NC group was not significantly altered $(\mathrm{P}>0.05$; Figure $7 \mathrm{~A}$ and $\mathrm{B})$. Conversely, compared with Model group, the apoptotic rates in the Ole groups were significantly increased (all $\mathrm{P}<0.001$; Figure 7A and B). In addition, following si-Notch 1 transfection into cells, the apoptotic rate in the Ole + si-Notch1 group was significantly decreased compared with that in the Ole groups (all $\mathrm{P}<0.001$; Figure 7A and B). With Notch1 knockdown, Ole's increasing cell apoptosis effects was disappear in $\mathrm{HaCaT}$ cell psoriasis model.
Notch1 knockdown downregulated the formation of autophagosomes in $\mathrm{HaCaT}$ cell psoriasis model. Formation of autophagosomes was observed using TEM. The results demonstrated that the number of autophagosomes in the model and model + si-NC groups was decreased (Figure 8). Conversely, following Ole intervention, the number of autophagosomes was increased; however, after si-Notch1 was transfected into cells, the number of autophagosomes in the Ole + si-Notch1 group was decreased. With Notch1 knockdown, Ole induced autophagosome increasing was depressed in $\mathrm{HaCaT}$ cell psoriasis model. 
A
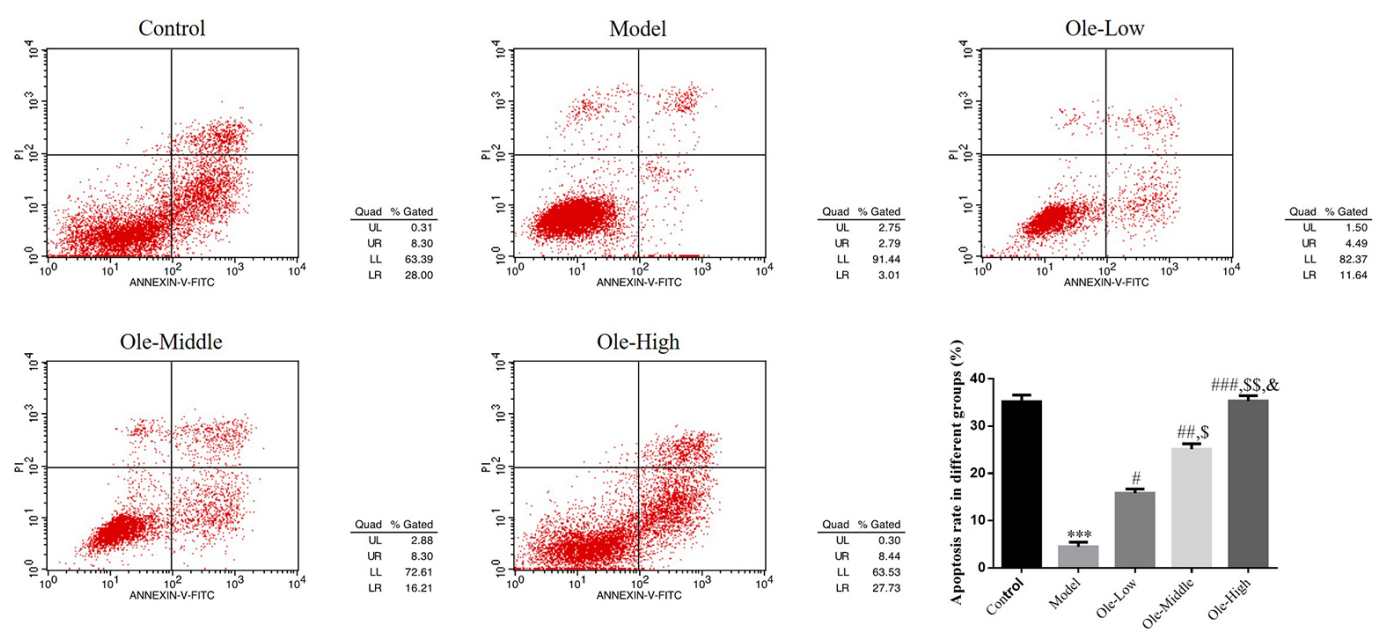

B
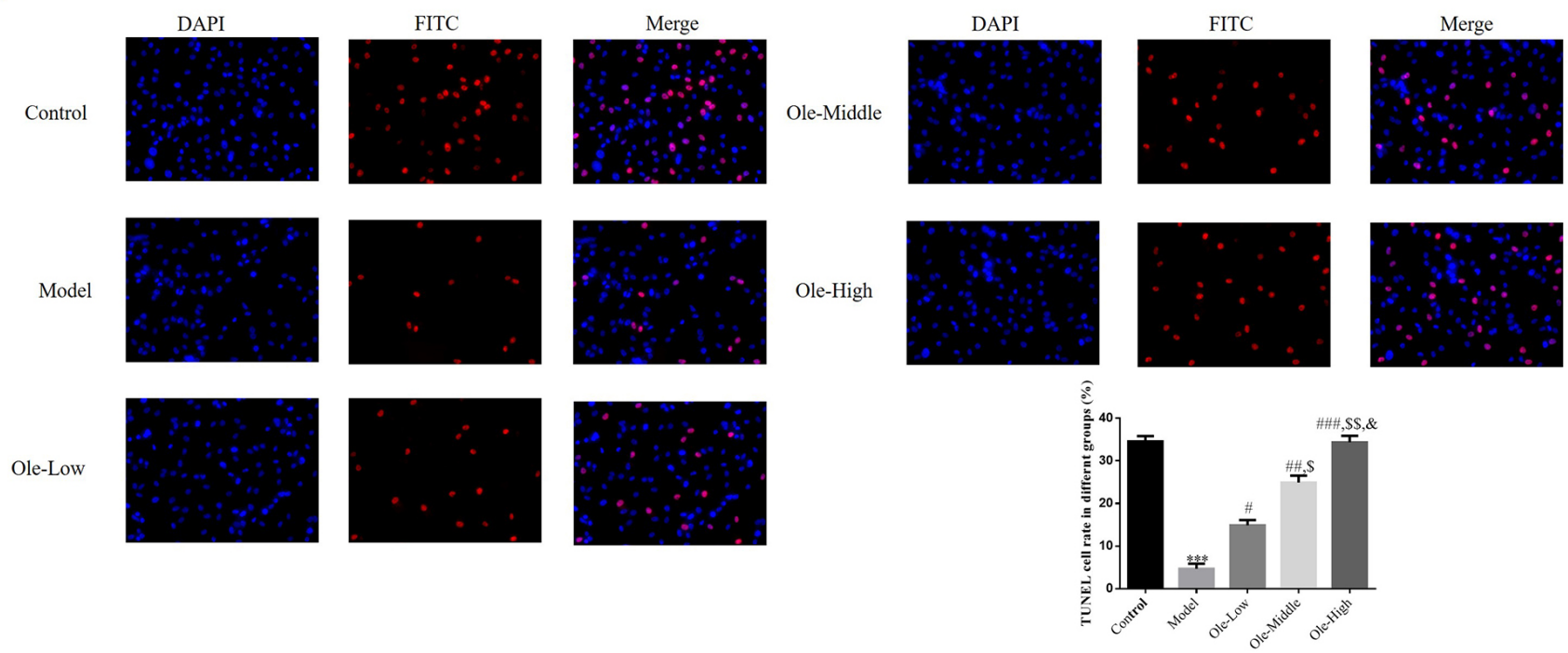

Figure 2. Effects of Ole on HaCaT cell apoptosis. Cell apoptotic rate was determined using (A) flow cytometry and (B) TUNEL assay. Control, $\mathrm{HaCaT}$ cells were treated with normal medium; model, HaCaT cells were stimulated with IL-22; Ole-low, model group cells were subsequently treated with low-dose $(25.0 \mu \mathrm{mol} / \mathrm{L})$ Ole; Ole-middle, model group cells were subsequently treated with middle-dose $(50.0 \mu \mathrm{mol} / \mathrm{L})$ Ole; Olehigh, model group cells were subsequently treated with high-dose $(100.0 \mu \mathrm{mol} / \mathrm{L})$ Ole. ${ }^{* * *} \mathrm{P}<0.001$ vs. control; ${ }^{*} \mathrm{P}<0.05$, ${ }^{\# *} \mathrm{P}<0.01$, ${ }^{* \# \#} \mathrm{P}<0.001$ vs. model; ${ }^{\$ \mathrm{P}}<0.05,{ }^{\$ \$} \mathrm{P}<0.01$ vs. Ole-low; ${ }^{\circledR} \mathrm{P}<0.05$ vs. Ole-middle. Ole, oleanolic acid.

Expression levels of Notch1, Hes1, Beclin1 and P62 proteins in $\mathrm{HaCaT}$ cell psoriasis model. Compared with the model group, the protein expression levels of Notch1, Hes1, beclin 1 and P62 in the model + si-NC group were not significantly altered (all P > 0.05; Figure 9). Compared with Model group, the protein expression levels of Notch1, Hes1 and beclin 1 were significantly upregulated in the Ole groups, while the protein expression levels of P62 were significantly downregulated (all P $<0.001$; Figure 9). Following the transfection of si-Notch1 into cells, compared with the Ole groups, the protein expression levels of Notch1, Hes1 and beclin 1 were significantly downregulated in the Ole + si-Notch1 group, while the protein expression levels of P62 were significantly upregulated (all P $<0.001$; Figure 9). With Notch1 knockdown, Ole induced Notch1,
Hes1, Beclin1 and P62 proteins changing was recovery in $\mathrm{HaCaT}$ cell psoriasis model.

Expression levels of LC3B protein in HaCaT cell psoriasis model The results of the immunofluorescence analysis revealed that, compared with the model group, the protein expression levels of LC3B in the model + si-NC group were not significantly altered $(P>0.05$; Figure 10). Compared with Model group, the protein expression levels of LC3B were significantly upregulated in the Ole groups (all $\mathrm{P}<0.001$; Figure 10). Following si-Notch1 transfection into cells, compared with the Ole groups, the protein expression levels of LC3B were found to be significantly downregulated in the Ole + si-Notch 1 group $(\mathrm{P}<0.001$; Figure 10$)$. With Notch1 knockdown, Ole induced LC3B proteins changing was recovery in $\mathrm{HaCaT}$ cell psoriasis model. 
Control

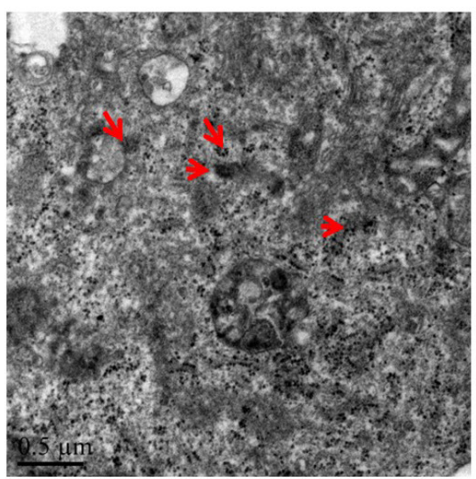

Model

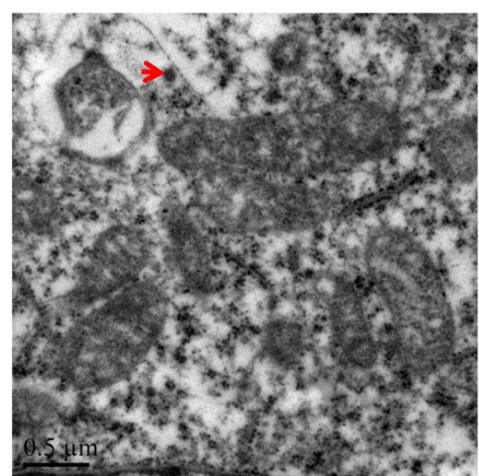

Ole-Low

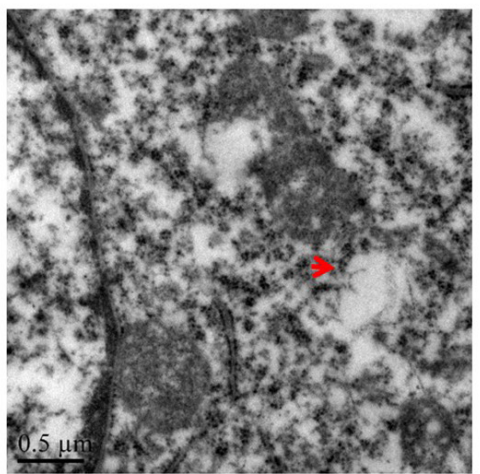

Ole-Middle

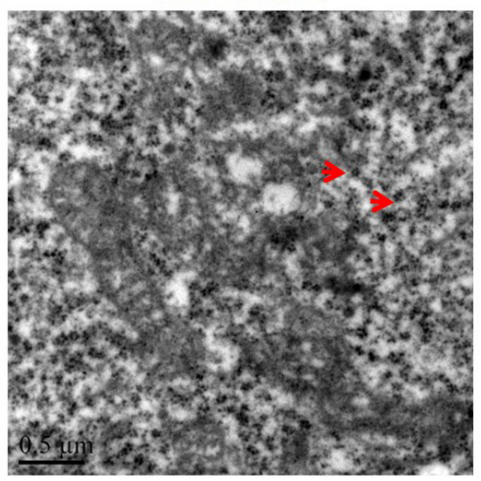

Ole-High

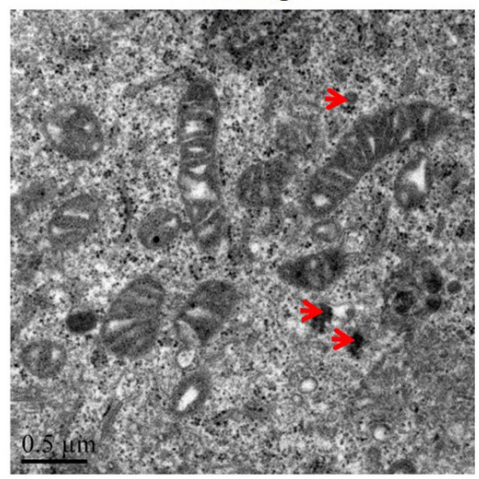

Figure 3. Effects of Ole on the autophagy of HaCaT cells. Control, HaCaT cells were treated with normal medium; model, HaCaT cells were stimulated with IL-22; Ole-low, model group cells were subsequently treated with low-dose $(25.0 \mu \mathrm{mol} / \mathrm{L})$ Ole; Ole-middle, model group cells were subsequently treated with middle-dose $(50.0 \mu \mathrm{mol} / \mathrm{L})$ Ole; Ole-high, model group cells were subsequently treated with high-dose $(100.0 \mu \mathrm{mol} / \mathrm{L}) \mathrm{Ole}$.
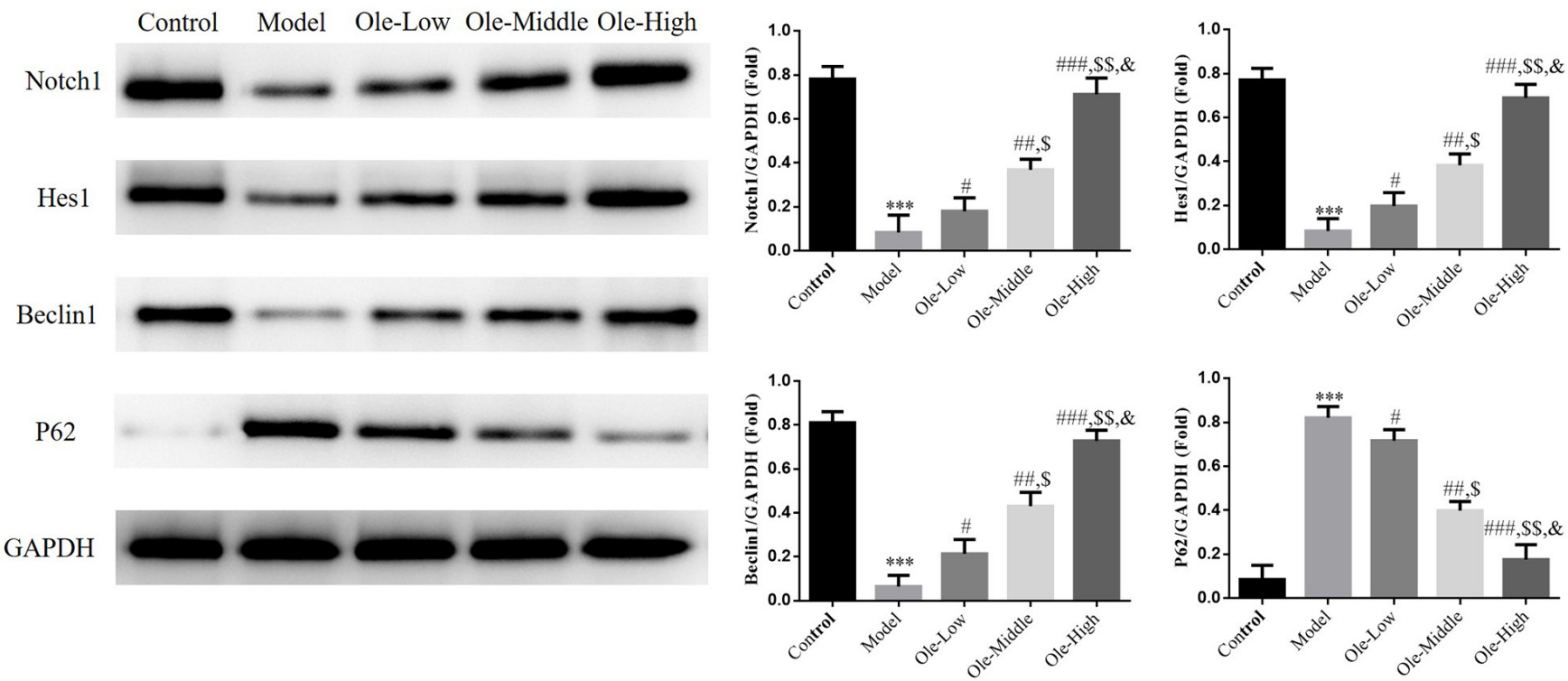

Figure 4. Effects of Ole on the expression levels of relevant proteins. Control, HaCaT cells were treated with normal medium; model, HaCaT cells were stimulated with IL-22; Ole-low, model group cells were subsequently treated with low-dose $(25.0 \mu$ mol/L) Ole; Ole-middle, model group cells were subsequently treated with middle-dose $(50.0 \mu \mathrm{mol} / \mathrm{L}) \mathrm{Ole}$; Ole-high, model group cells were subsequently treated with high-dose $(100.0 \mu \mathrm{mol} / \mathrm{L})$ Ole. ${ }^{* * *} \mathrm{P}<0.001$ vs. control; ${ }^{*} \mathrm{P}<0.05,{ }^{* \#} \mathrm{P}<0.01,{ }^{\# \# *} \mathrm{P}<0.001$ vs. model; ${ }^{\$} \mathrm{P}<0.05,{ }^{\$ \$} \mathrm{P}<0.01$ vs. Ole-low; ${ }^{*} \mathrm{P}<0.05$ vs. Ole-middle. Ole, oleanolic acid. 

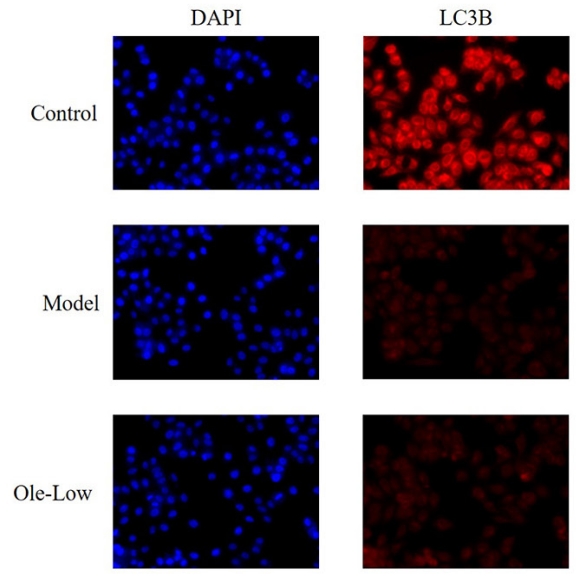
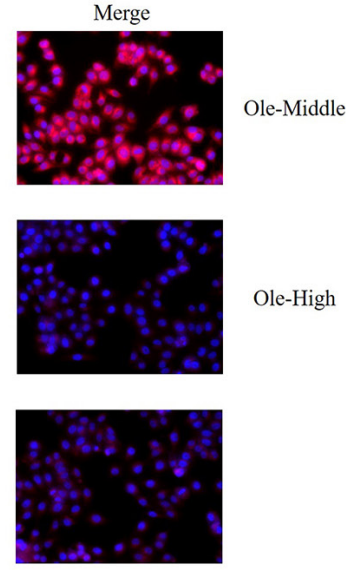

DAPI
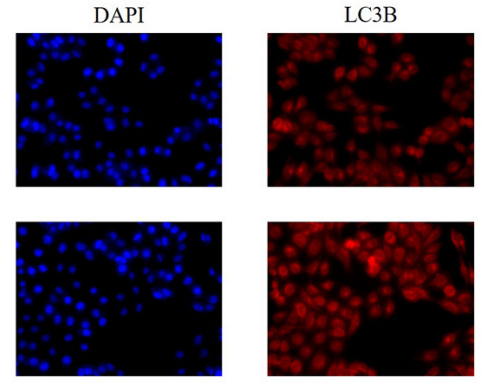
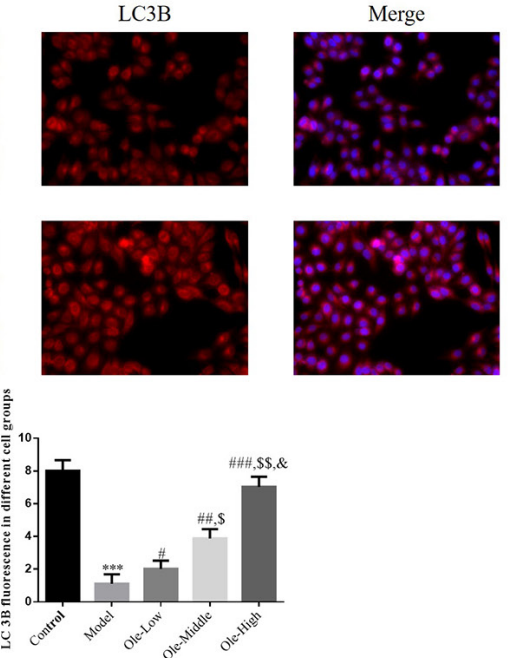

Figure 5. Effects of Ole on the protein expression of LC3B. Control, HaCaT cells were treated with normal medium; model, HaCaT cells were stimulated with IL-22; Ole-low, model group cells were subsequently treated with low-dose $(25.0 \mu \mathrm{mol} / \mathrm{L})$ Ole; Ole-middle, model group cells were subsequently treated with middle-dose $(50.0 \mu \mathrm{mol} / \mathrm{L})$ Ole; Ole-high, model group cells were subsequently treated with high-dose $(100.0$ $\mu \mathrm{mol} / \mathrm{L})$ Ole. ${ }^{* * *} \mathrm{P}<0.001$ vs. control; ${ }^{*} \mathrm{P}<0.05,{ }^{* \#} \mathrm{P}<0.01,{ }^{\# \# *} \mathrm{P}<0.001$ vs. model; ${ }^{\$} \mathrm{P}<0.05,{ }^{\$ \$} \mathrm{P}<0.01$ vs. Ole-low; ${ }^{\text {\& }} \mathrm{P}<0.05$ vs. Ole-middle. Ole, oleanolic acid.

\section{Discussion}

As a natural pentacyclic triterpenoid, Ole has been reported to exert antitumor and anti-inflammatory effects (Wang et al. 2019; Abdelmageed et al. 2017), and has been shown to be effective in the treatment of multiple types of tumor (Chu et al. 2017; Dong et al. 2020; Han et al. 2021). The results of the present study revealed that Ole intervention could effectively inhibit the abnormal proliferation of $\mathrm{HaCaT}$ cells induced by IL-22 stimulation and promote their apoptosis, which may subsequently inhibit the development of psoriasis. Autophagy is a protective mechanism that occurs in eukaryotic cells. It removes dysfunctional and denatured, damaged organelles, macromolecules and invading microorganisms by forming autophagic lysosomes, thereby maintaining cell homeostasis and renewal (White et al. 2010; Mizushima \& Komatsu, 2011). LC3B is a characteristic marker of autophagy, and the expression levels of LC3B reflect the autophagy level (Satyavarapu et al. 2018). The findings of the current study demonstrated that, following Ole intervention, the number of autophagosomes was increased, the protein expression levels of autophagy marker proteins, Hes1 (Yao et al. 2015), beclin 1 (Maejima et al. 2016) and LC3B (Satyavarapu et al. 2018), were significantly upregulated, and the protein expression levels of P62 (Lamark et al. 2017) were significantly downregulated. The highly conserved Notch gene family was first discovered in Drosophila melanogaster by Morgan et al. in 1917, and comprises four transmembrane receptors, Notch1, Notch2, Notch3 and Notch4, which are involved in regulating the viability, proliferation and differentiation of cells and the development of organs (Nantie et al. 2014; Ebens \& Maillard, 2013). Previous studies have reported that the upregulated expression of Notch1 promoted the autophagy of cells (Xu et al. 2019, Lee et al. 2020). Similarly, the results of the present study also showed that the protein expression levels of Notch1 were significantly increased Ole treated groups. Therefore, it was hypothesized that

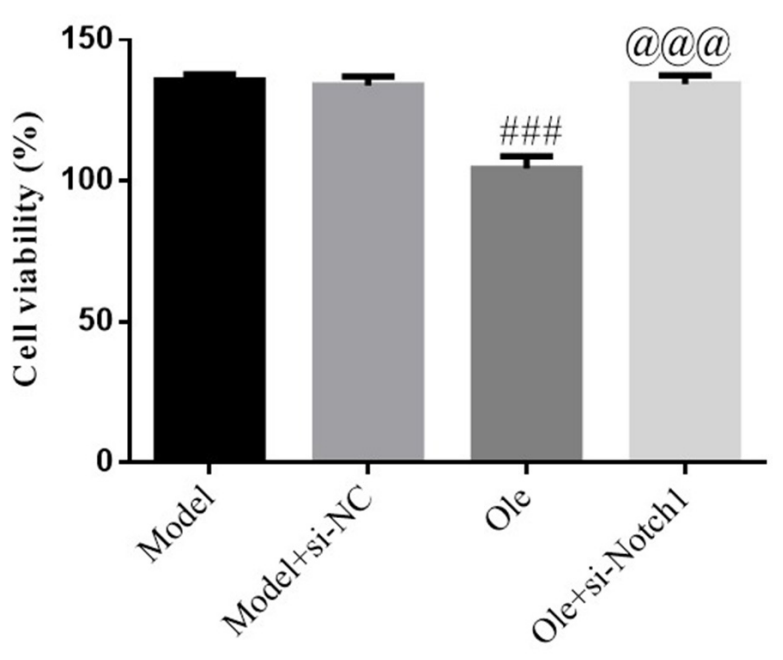

Figure 6. Role of Notch1 in the Ole-induced inhibition of $\mathrm{HaCaT}$ proliferation. Model, HaCaT cells were stimulated with IL-22; model + si-NC, model group cells were transfected with si-NC; Ole, HaCaT cells were stimulated with IL-22 and treated with $100.0 \mu \mathrm{mol} / \mathrm{L}$ Ole; Ole + si-Notch1, HaCaT cells transfected with si-Notch1 were stimulated with IL-22 and treated with $100.0 \mu \mathrm{mol} / \mathrm{L}$ Ole. ${ }^{\# \# \#} \mathrm{P}<0.001 \mathrm{vs}$. model; $@ @ @ P<0.001$ vs. Ole. Ole, oleanolic acid; si, small interfering RNA; NC, negative control; Notch1, notch 1 receptor.

Ole may play an important role in reversing the IL-22-induced excessive proliferation of $\mathrm{HaCaT}$ cells by increasing autophagy via upregulation of Notch1. Furthermore, the therapeutic effect of Ole was reduced after the expression of Notch1 was knocked down by transfection with si-Notch1. These findings suggested 
A
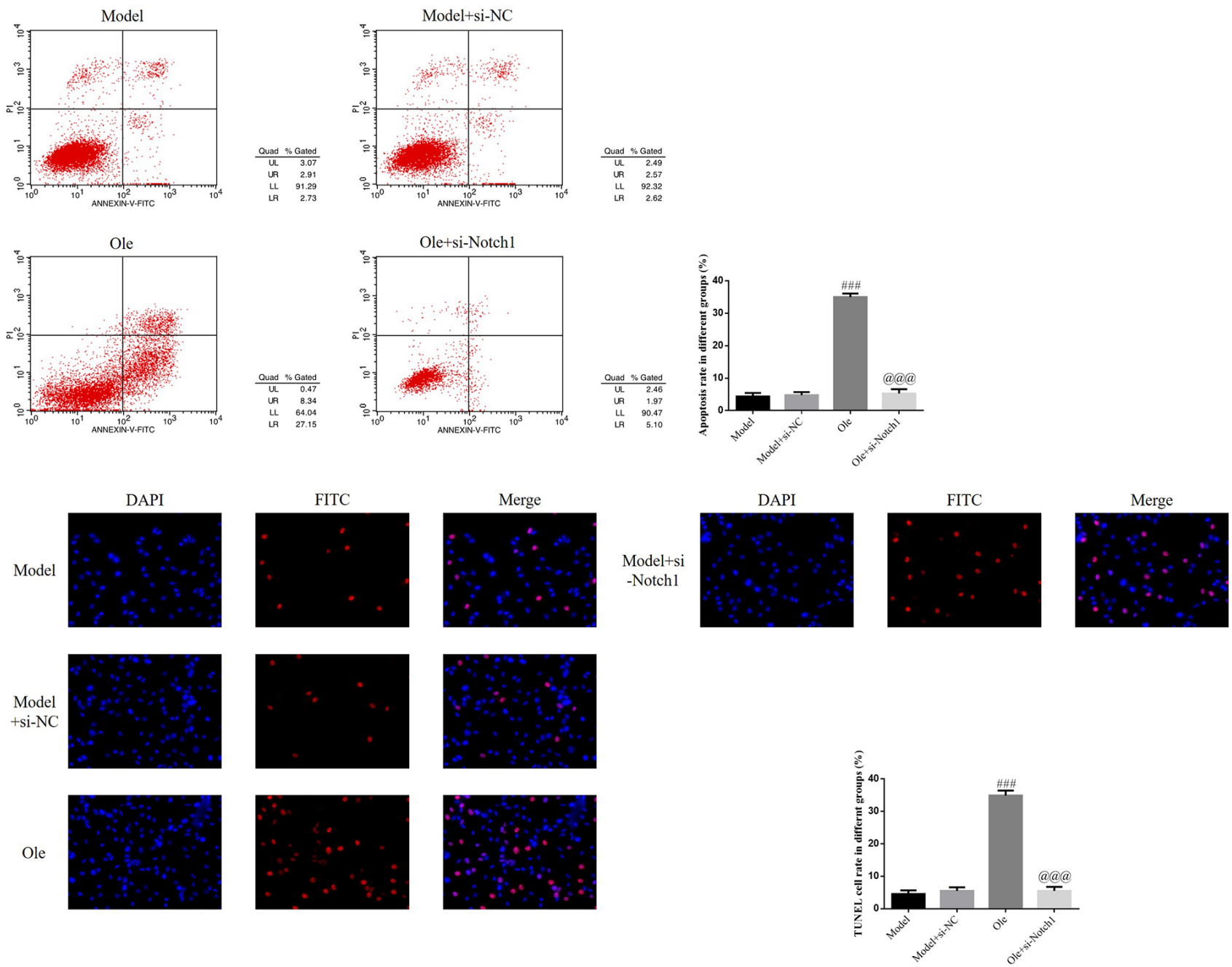

Figure 7. Role of Notch1 in the Ole-induced stimulation of the apoptosis of HaCaT cells. Apoptotic rate of different groups was determined using (A) flow cytometry and (B) a TUNEL assay. Model, HaCaT cells were stimulated with IL-22; model + si-NC, model group cells were transfected with si-NC; Ole, HaCaT cells were stimulated with IL-22 and treated with $100.0 \mu \mathrm{mol} / \mathrm{L}$ Ole; Ole + si-Notch1, HaCaT cells transfected with siNotch1 were stimulated with IL-22 and treated with $100.0 \mu \mathrm{mol} / \mathrm{L}$ Ole. ${ }^{\# \#} \mathrm{P}<0.001$ vs. model; ${ }^{\circledR @} \mathrm{P}<0.001$ vs. Ole. Ole, oleanolic acid; si, small interfering RNA; NC, negative control; Notch1, notch 1 receptor.

that Notch1 may play a crucial role in the Ole-induced decrease in the IL-22-induced proliferation of HaCaT cells.

The findings of the current study also revealed that treatment with 25,50 or $100 \mu \mathrm{mol} / \mathrm{L}$ Ole was non-toxic to HaCaT cells in a normal environment, but could inhibit the IL-22-induced proliferation of $\mathrm{HaCaT}$ cells. Moreover, the inhibition of proliferation occurred in both a time- and dose-dependent manner. Treatment with 25,50 or $100 \mu \mathrm{mol} / \mathrm{L}$ Ole could also significantly increase the apoptotic rate of $\mathrm{HaCaT}$ cells in a dose-dependent manner. Similarly, 25, 50 or $100 \mu \mathrm{mol} / \mathrm{L}$ Ole was discovered to induce the autophagy of $\mathrm{HaCaT}$ cells. Ole treatment also upregulated the protein expression levels of Hes 1 and beclin 1, and downregulated those of P62. Immunofluorescence analysis further revealed that the number of LC3B-fluorescing accumulation points was increased and TEM analysis observed the presence of autophagosomes with bilayer membranes, proving that the autophagy levels of cells were increased, while degradation of P62 was increased. However, following the transfection of si-Notch 1 into cells, the effects of Ole on the cells disappeared.

There were certain limitations to the present study. First, a positive control drug group was not used. Second, only in vitro cellular studies were performed, and the effects of Ole on an imiquimod-induced psoriasis animal model were not investigated. Finally, considering that mTOR serves an important role in autophagy, the present study did not determine the association between mTOR and Notch1 during Ole treatment, in our study, we just discussed autophagy (autophagosome changing) in Ole's affects to positively cell model, the lysosomes' effects had been unclear; meanwhile, there were no Model+si-Notch1 and Ole+siNC groups in second part of our present research. Therefore, these points will be addressed in future studies, with the effects of Ole on animal models of psoriasis being prioritized. 

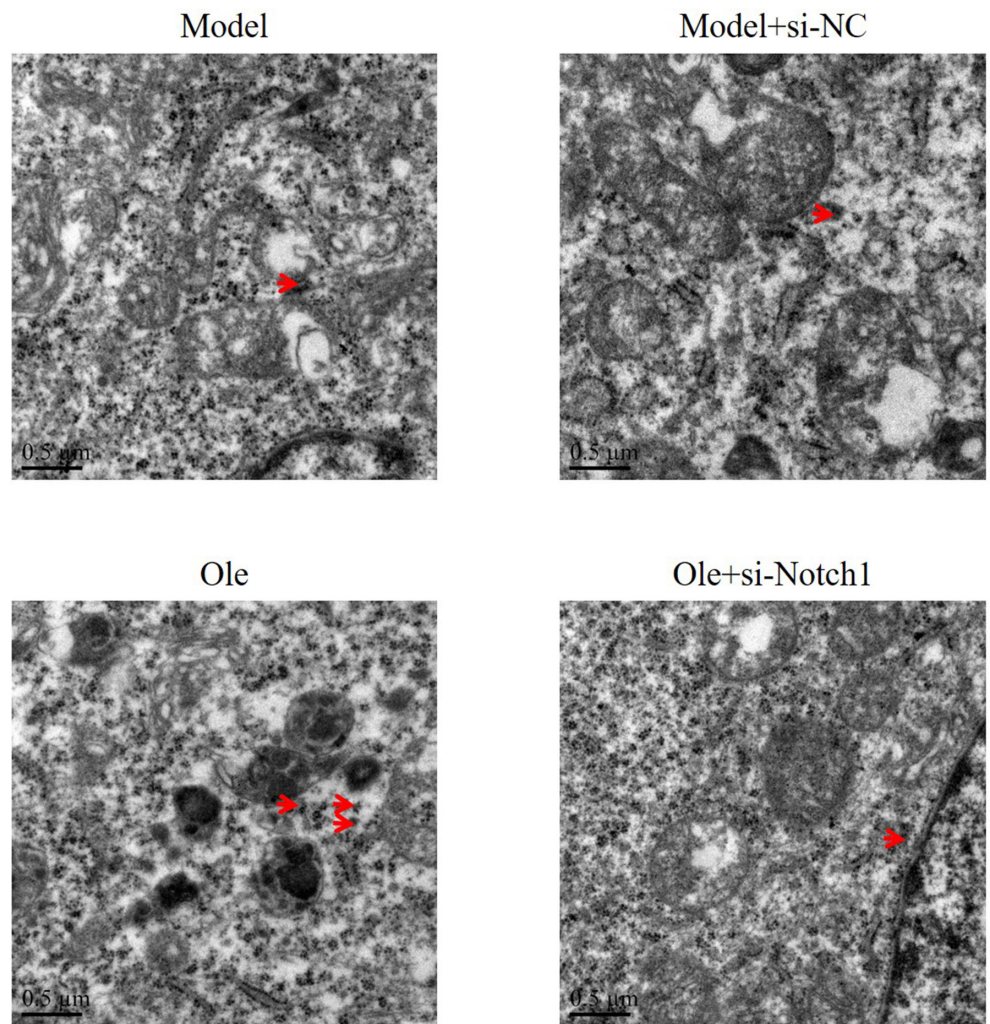

Figure 8. Effects of Notch1 on autophagosome formation. Model, HaCaT cells were stimulated with IL-22; model + si-NC, model group cells were transfected with si-NC; Ole, HaCaT cells were stimulated with IL-22 and treated with $100.0 \mu \mathrm{mol} / \mathrm{L}$ Ole; Ole + si-Notch1, HaCaT cells transfected with si-Notch1 were stimulated with IL-22 and treated with $100.0 \mu \mathrm{mol} / \mathrm{L}$ Ole. Ole, oleanolic acid; si, small interfering RNA; NC, negative control; Notch1, notch 1 receptor.
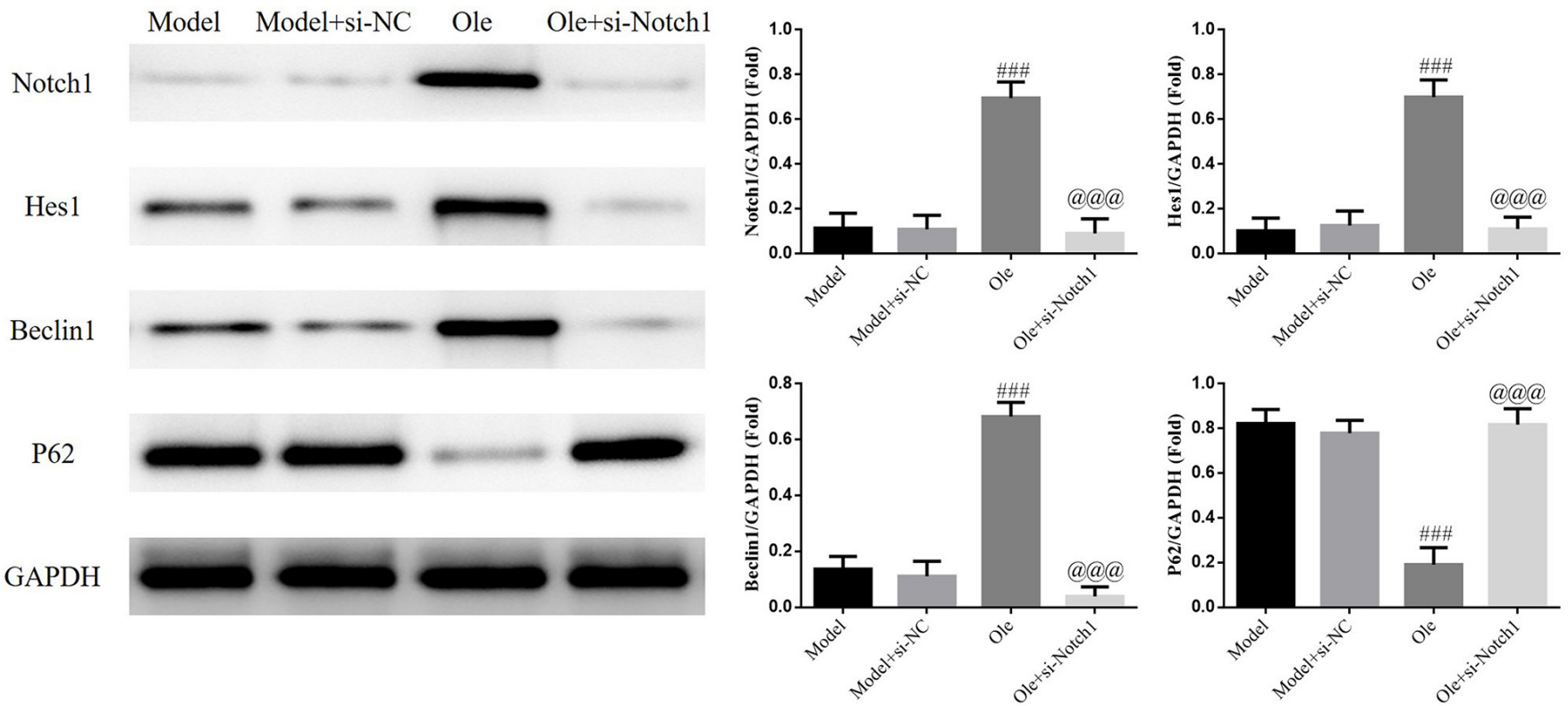

Figure 9. Detection of the expression levels of relevant proteins using western blotting. Model, HaCaT cells were stimulated with IL-22; model + si-NC, model group cells were transfected with si-NC; Ole, HaCaT cells were stimulated with IL-22 and treated with 100.0 $\mu$ mol/L Ole; Ole + si-Notch1, HaCaT cells transfected with si-Notch1 were stimulated with IL-22 and treated with $100.0 \mu$ mol/L Ole. ${ }^{\# \# \# ~} \mathrm{P}<0.001$ vs. model; $@ @ @ P<0.001$ vs. Ole. Ole, oleanolic acid; si, small interfering RNA; NC, negative control; Notch1, notch 1 receptor. 

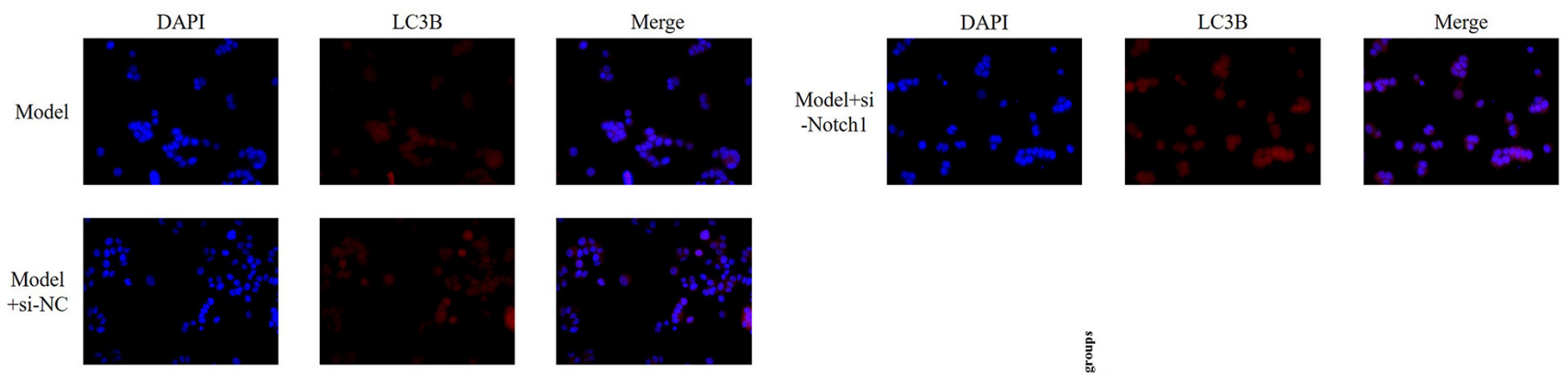

Ole
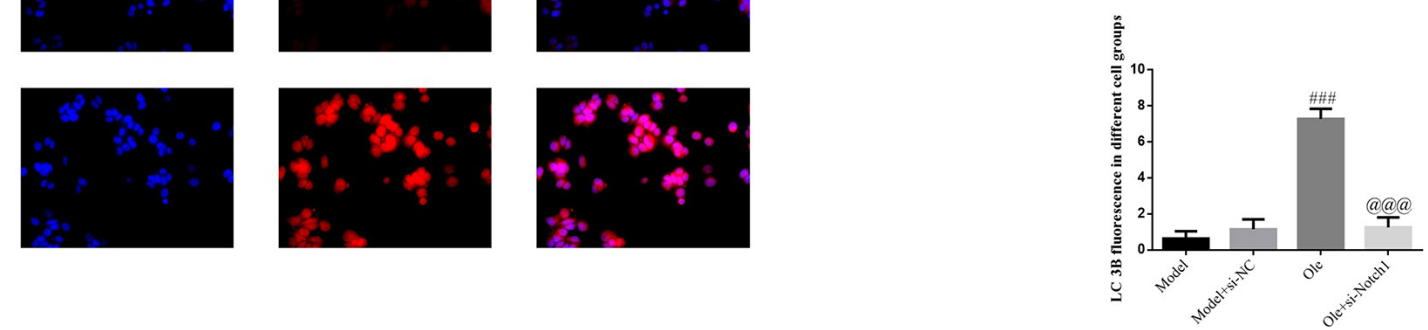

Figure 10. Detection of the protein expression levels of LC3B using immunofluorescence. Model, HaCaT cells were stimulated with IL-22; model + si-NC, model group cells were transfected with si-NC; Ole, HaCaT cells were stimulated with IL-22 and treated with 100.0 $\mu$ mol/L Ole; Ole + si-Notch1, HaCaT cells transfected with si-Notch1 were stimulated with IL-22 and treated with $100.0 \mu$ mol/L Ole. ${ }^{\# \# P} \mathrm{P}<0.001$ vs. model; $\varrho^{\circledR} \mathrm{P}<0.001$ vs. Ole. Ole, oleanolic acid; si, small interfering RNA; NC, negative control; Notch1, notch 1 receptor.

In conclusion, the findings of the current study suggested that Ole may inhibit the excessive proliferation of the IL-22-induced $\mathrm{HaCaT}$ cell psoriasis model. The underlying mechanism of action of Ole was suggested to be associated with its ability to activate HaCaT cell autophagy by positively regulating Notch1 expression.

\section{References}

Abdelmageed, N., Morad, S. A. F., Elghoneimy, A. A., Syrovets, T., Simmet, T., El-Zorba, H., El-Banna, H. A., Cabot, M., \& AbdelAziz, M. I. (2017). Oleanolic acid methyl ester, a novel cytotoxic mitocan, induces cell cycle arrest and ROS-Mediated cell death in castration-resistant prostate cancer PC-3 cells. Biomedicine and Pharmacotherapy, 96, 417-425. http://dx.doi.org/10.1016/j. biopha.2017.10.027. PMid:29031200.

Chen, J., Cui, Y., Zhang, N., Yao, X., Wang, Z., \& Yang, L. (2019). Oleanolic acid attenuated diabetic mesangial cell injury by activation of autophagy via miRNA-142-5p/PTEN signaling. Cytotechnology, 71(5), 925-933. http://dx.doi.org/10.1007/s10616-019-00335-0. PMid:31410746.

Chu, P., Li, H., Luo, R., Ahsan, A., Qaed, E., Shopit, A., Ma, X., Lin, Y., Peng, J., Zhang, J., Wang, S., \& Tang, Z. (2017). Oleanolic acid derivative SZC014 inhibit cell proliferation and induce apoptosis of human breast cancer cells in a ROS-dependent way. Neoplasma, 64(5), 681-692.http://dx.doi.org/10.4149/neo_2017_505.PMid:28592114.

Dong, N., Xue, C., Zhang, L., Zhang, T., Wang, C., Bi, C., \& Shan, A. (2020). Oleanolic acid enhances tight junctions and ameliorates inflammation in Salmonella typhimurium-induced diarrhea in mice via the TLR4/NF-kappaB and MAPK pathway. Food \& Function, 11(1), 1122-1132. http://dx.doi.org/10.1039/C9FO01718F. PMid:31825448.

Ebens, C. L., \& Maillard, I. (2013). Notch signaling in hematopoietic cell transplantation and T cell alloimmunity. Blood Reviews, 27(6), 269277. http://dx.doi.org/10.1016/j.blre.2013.08.001. PMid:24050990.

Griffiths, C. E. M., Walt, J. M., Ashcroft, D. M., Flohr, C., Naldi, L., Nijsten, T., \& Augustin, M. (2017). The global state of psoriasis disease epidemiology: a workshop report. The British Journal of
Dermatology, 177(1), e4-e7. http://dx.doi.org/10.1111/bjd.15610. PMid:28555722.

Guo, Q., He, J., Zhang, H., Yao, L., \& Li, H. (2020). Oleanolic acid alleviates oxidative stress in Alzheimer's disease by regulating stanniocalcin-1 and uncoupling protein-2 signalling. Clinical and Experimental Pharmacology \& Physiology, 47(7), 1263-1271. http:// dx.doi.org/10.1111/1440-1681.13292. PMid:32100892.

Han, Y., Tong, Z., Wang, C., Li, X., \& Liang, G. (2021). Oleanolic acid exerts neuroprotective effects in subarachnoid hemorrhage rats through SIRT1-mediated HMGB1 deacetylation. European Journal of Pharmacology, 893, 173811. http://dx.doi.org/10.1016/j. ejphar.2020.173811. PMid:33345851.

Haruna, K., Suga, Y., Muramatsu, S., Taneda, K., Mizuno, Y., Ikeda, S., Ueno, T., Kominami, E., Tanida, I., Tanida, I., \& Hanada, K. (2008). Differentiation-specific expression and localization of an autophagosomal marker protein (LC3) in human epidermal keratinocytes. Journal of Dermatological Science, 52(3), 213-215. http://dx.doi.org/10.1016/j.jdermsci.2008.07.005. PMid:18760570.

Jo, E. K., Shin, D. M., \& Choi, A. M. (2012). Autophagy: cellular defense to excessive inflammation. Microbes and Infection, 14(2), 119-125. http://dx.doi.org/10.1016/j.micinf.2011.08.014. PMid:21924374.

Lamark, T., Svenning, S., \& Johansen, T. (2017). Regulation of selective autophagy: the p62/SQSTM1 paradigm. Essays in Biochemistry, 61(6), 609-624. http://dx.doi.org/10.1042/EBC20170035. PMid:29233872.

Lee, H. M., Shin, D. M., Yuk, J. M., Shi, G., Choi, D. K., Lee, S. H., Huang, S. M., Kim, J. M., Kim, C. D., Lee, J. H., \& Jo, E. K. (2011). Autophagy negatively regulates keratinocyte inflammatory responses via scaffolding protein p62/SQSTM1. Journal of Immunology, 186(2), 1248-1258. http://dx.doi.org/10.4049/jimmunol.1001954. PMid:21160040.

Lee, S., Kim, S. K., Park, H., Lee, Y. J., Park, S. H., Lee, K. J., Lee, D. G., Kang, H., \& Kim, J. E. (2020). Contribution of Autophagy-Notch1Mediated NLRP3 inflammasome activation to chronic inflammation and fibrosis in keloid fibroblasts. International Journal of Molecular Sciences, 21(21), 8050. http://dx.doi.org/10.3390/ijms21218050. PMid:33126764. 
Maejima, Y., Isobe, M., \& Sadoshima, J. (2016). Regulation of autophagy by Beclin 1 in the heart. Journal of Molecular and Cellular Cardiology, 95, 19-25. http://dx.doi.org/10.1016/j.yjmcc.2015.10.032. PMid:26546165.

Mizushima, N., \& Komatsu, M. (2011). Autophagy: renovation of cells and tissues. Cell, 147(4), 728-741. http://dx.doi.org/10.1016/j. cell.2011.10.026. PMid:22078875.

Nantie, L. B., Himes, A. D., Getz, D. R., \& Raetzman, L. T. (2014). Notch signaling in postnatal pituitary expansion: proliferation, progenitors, and cell specification. Molecular Endocrinology, 28(5), 731-744. http://dx.doi.org/10.1210/me.2013-1425. PMid:24673559.

Perera, G. K., Meglio, P., \& Nestle, F. O. (2012). Psoriasis. Annual Review of Pathology, 7(1), 385-422. http://dx.doi.org/10.1146/annurevpathol-011811-132448. PMid:22054142.

Satyavarapu, E. M., Das, R., Mandal, C., Mukhopadhyay, A., \& Mandal, C. (2018). Autophagy-independent induction of LC3B through oxidative stress reveals its non-canonical role in anoikis of ovarian cancer cells. Cell Death \& Disease, 9(10), 934. http://dx.doi.org/10.1038/ s41419-018-0989-8. PMid:30224639.

Song, Y., Zhang, P., Sun, Y., Li, X., Chen, L., Xiao, Y., \& Xing, Y. (2017). AMPK activation-dependent autophagy compromises oleanolic acidinduced cytotoxicity in human bladder cancer cells. Oncotarget, 8(40), 67942-67954. http://dx.doi.org/10.18632/oncotarget.18980. PMid:28978086.

Varshney, P., \& Saini, N. (2018). PI3K/AKT/mTOR activation and autophagy inhibition plays a key role in increased cholesterol during IL-17A mediated inflammatory response in psoriasis. Biochimica et Biophysica Acta. Molecular Basis of Disease, 1864(5PtA), 1795-1803. http://dx.doi.org/10.1016/j.bbadis.2018.02.003. PMid:29432814.

Wang, H., Zhong, W., Zhao, J., Zhang, H., Zhang, Q., Liang, Y., Chen, S., Liu, H., Zong, S., Tian, Y., Zhou, H., Sun, T., Liu, Y., \& Yang, C. (2019). Oleanolic acid inhibits epithelial-mesenchymal transition of hepatocellular carcinoma by promoting iNOS dimerization. Molecular Cancer Therapeutics, 18(1), 62-74. http://dx.doi.org/10.1158/15357163.MCT-18-0448. PMid:30297361.

Wang, J., Ren, C., Feng, J., Ou, C., \& Liu, L. (2020). Oleanolic acid inhibits mouse spinal cord injury through suppressing inflammation and apoptosis via the blockage of p38 and JNK MAPKs. Biomedicine and Pharmacotherapy, 123, 109752. http://dx.doi.org/10.1016/j. biopha.2019.109752. PMid:31924596.
White, E., Karp, C., Strohecker, A. M., Guo, Y., \& Mathew, R. (2010). Role of autophagy in suppression of inflammation and cancer. Current Opinion in Cell Biology, 22(2), 212-217. http://dx.doi.org/10.1016/j. ceb.2009.12.008. PMid:20056400.

Wu, S., Zhao, M., Sun, Y., Xie, M., Le, K., Xu, M., \& Huang, C. (2020). The potential of Diosgenin in treating psoriasis: Studies from HaCaT keratinocytes and imiquimod-induced murine model. Life Sciences, 241, 117115. http://dx.doi.org/10.1016/j.lfs.2019.117115. PMid:31790685.

Xu, Y., Li, Y., Liu, X., Pan, Y., Sun, Z., Xue, Y., Wang, T., Dou, H., \& Hou, Y. (2019). SPIONs enhances IL-10-producing macrophages to relieve sepsis via Cav1-Notch1/HES1-mediated autophagy. International Journal of Nanomedicine, 14, 6779-6797. http://dx.doi.org/10.2147/ IJN.S215055. PMid:31692534.

Yao, J., Zheng, K., Li, C., Liu, H., \& Shan, X. (2015). Interference of Notch1 inhibits the growth of glioma cancer cells by inducing cell autophagy and down-regulation of Notch1-Hes-1 signaling pathway. Medical Oncology, 32(6), 610. http://dx.doi.org/10.1007/ s12032-015-0610-2. PMid:25920606.

Zhang, T., Wu, P., Budbazar, E., Zhu, Q., Sun, C., Mo, J., Peng, J., Gospodarev, V., Tang, J., Shi, H., \& Zhang, J. H. (2019a). Mitophagy reduces oxidative stress via Keap1 (Kelch-like epichlorohydrinassociated protein 1)/Nrf2 (Nuclear Factor-E2-Related Factor 2)/PHB2 (prohibitin 2) pathway after subarachnoid hemorrhage in rats. Stroke, 50(4), 978-988. http://dx.doi.org/10.1161/STROKEAHA.118.021590. PMid:30890112.

Zhang, Y., Xiang, Z., Jia, Y., He, X., Wang, L., \& Cui, W. (2019b). The Notch signaling pathway inhibitor Dapt alleviates autism-like behavior, autophagy and dendritic spine density abnormalities in a valproic acid-induced animal model of autism. Progress in Neuro-Psychopharmacology \& Biological Psychiatry, 94, 109644. http://dx.doi.org/10.1016/j.pnpbp.2019.109644. PMid:31075347.

Zhou, W., Zeng, X., \& Wu, X. (2020). Effect of oleanolic acid on apoptosis and autophagy of SMMC-7721 hepatoma cells. Medical Science Monitor, 26, e921606. http://dx.doi.org/10.12659/MSM.921606. PMid:32424110.

Zolnourian, A., Galea, I., \& Bulters, D. (2019). Neuroprotective role of the Nrf2 pathway in subarachnoid haemorrhage and its therapeutic potential. Oxidative Medicine and Cellular Longevity, 2019, 6218239. http://dx.doi.org/10.1155/2019/6218239. PMid:31191800. 


\section{Supplementary Material}

Supplementary material accompanies this paper.

Supplementary Figure 1. Notch1 mRNA expression in difference groups NC: HaCaT cells were treated with normal medium; si-NC: HaCaT cells were transfected with si-NC; si-Notch1: HaCaT cells were transfected with si-Notch1. ${ }^{* *}: \mathrm{P}<0.001$, compared with NC group

This material is available as part of the online article from https://www.scielo.br/j/IDSCIELO 